\title{
Determinan Permintaan Motor Kredit Pada PT. Federal International Finance (FIF) di Kabupaten Manokwari
}

\author{
Yuyun P. Rahayu', Elina R. Situmorang', Yospin Pasiamping ${ }^{2}$ \\ ${ }^{1}$ Dosen Fakultas Ekonomi Dan Bisnis, Universitas Papua \\ ${ }^{2}$ Alumni Fakultas Ekonomi Dan Bisnis, Universitas Papua \\ Permalink/DOI: http://dx.doi.org/10.32830/jfres.v1i1.1019.g763
}

Received: Juny 2018; Accepted: August 2018; Published: September 2018

\begin{abstract}
Abstrak
Tujuan penelitian ini untuk faktor penentu permintaan kredit sepeda motor Honda di Kabupaten Manokwari, tepatnya pada PT. Federal International Finance (FIF). Metode analisis yang digunakan adalah metode analisis statistik deskriptif dengan wawancara dan kuesioner. Analisis data dilakukan menggunakan alat analisis regresi linear berganda. Hasil penelitian deskriptif menunjukkan bahwa pertumbuhan permintaan kredit di Kabupaten Manokwari tahun 2011-2014 menunjukan adanya peningkatan. Hal ini di sebabkan karena sepeda motor merupakan alat transportasi yang efisien dan irit sehingga masyarakat lebih memilih untuk mengggunakannya dari pada transpotasi lainnnya, seperti mobil. Selanjutnya, hasil penelitian menunjukan bahwa dari keempat variabel yang digunakan dalam penelitian ini yaitu pendapatan, jangka waktu pengembalian kredit, harga produk dan barang subtitusi secara simultan atau secara bersama-sama berpengaruh positif dan signifikan terhadap permintaan kredit sepeda motor Honda di Kabupaten Manokwari. Sedangkan secara parsial hanya jangka waktu pengembalian kredit yang tidak berpengaruh terhadap permintaan kredit sepeda motor Honda.
\end{abstract}

Kata kunci: pendapatan, jangka waktu pengembalian kredit, harga produk, barang subtitusi, permintaan kredit

\begin{abstract}
Purpose of this study is to analyze determinant factors influencing the demand for Honda motorcycle credit at PT. Federal International Finance (FIF) Manokwari Regency. Descriptive statistics analysis method is used. Data was collected by interviews and questionnaires. Data analysis was performed using multiple linear regression analysis tools. The results show that the growth of credit demand in Manokwari Regency from 2011 to 2014 showed an increase. This because the use of motorbikes are efficient and economical as transportation. Thus, people prefer to use it rather than other transportation, such as cars. Furthermore, result of this study is that of the four variables used (income, credit payment period, the price of substituted products and goods) simultaneously have a positive and significant effect on the demand for Honda motorcycle credit in Manokwari Regency. While partially, only the credit payment period does not affect the demand for Honda motorcycle credit.
\end{abstract}

Keywords: income, credit return period, product price, substitute goods, credit request

How to Cite: Rahayu, Y.P., Situmorang, E.R., Pasiamping, Y. (2018). Determinan Permintaan Motor Kredit Pada PT. Federal International Finance (FIF) di Kabupaten Manokwari. JFRES: Journal of Fiscal and Regional Economy Studies, 1 (1), 35-45.

doi: http://dx.doi.org/10.32830/jfres.v1i1.1019.g763 


\section{PENDAHULUAN}

Peningkatan kesejahteraan masyarakat dapat dicapai dengan bantuan pemerintah dan swasta, salah satu caranya adalah dengan memberikan kredit kepada masyarakat. Pemerintah memberikan kredit kepada masyarakat disalurkan melalui lembaga bank dan non-bank yang mempunyai pengaruh sangat besar untuk peningkatan pendapatan dan kesejahteraan masyarakat. Sedangkan, pihak swasta melibatkan perusahaan penyalur kendaraan roda dua (dealer) dengan cara penyediaan kredit sepeda motor.

Permintaan kredit sepeda motor yang semakin meningkat, terjadi karena adanya kemudahan untuk membeli sepeda motor dengan jalur kredit. Hal tersebut dapat dibuktikan dengan banyaknya iklan-iklan dealer penjualan sepeda motor yang memberikan kemudahan pembelian melalui jalur kredit dengan syarat yang sederhana. Ada empat dealer yang terdapat di Kabupaten Manokwari, Papua Barat diantaranya dealer Honda, Suzuki, Yamaha dan Kawasaki. Dengan munculnya berbagai perusahaan tersebut maka perusahaan dituntut untuk menciptakan berbagai inovasi baik dari segi mutu maupun dari segi desain. Dari antara keempat dealer tersebut maka yang akan diambil dan dibahas dalam penelitian ini adalah permintaan kredit sepeda motor merek Honda pada PT. Federal International Finance (FIF).

Federal International Finance (FIF) adalah perusahaan yang bergerak dibidang pembiayaan (leasing) dimana salah satu perusahaan yang menyediakan kredit bagi konsumen. Leasing berperan sebagai perantara produsen sepeda motor (pabrikan), penyedia barang dengan konsumen dan pengguna barang. Perkembangan leasing saat ini cukup signifikan karena fungsinya yang setingkat bank. Salah satu contohnya adalah leasing sepeda motor merek Honda. Leasing sepeda motor Honda pada PT.FIF di Kabupaten Manokwari tidak hanya menyediakan kredit sepeda motor baru melainkan juga menyediakan kredit sepeda motor second, dengan adanya kredit sepeda motor second akan mempermudah konsumen melakukan permintaan kredit karena harga yang di berikan terjangkau. Kemudahan dalam pembelian sepeda motor oleh masyarakat berdampak pada peningkatan volume sepeda motor.

Tabel 1. Perkembangan Jumlah Sepeda Motor di Kabupaten Manokwari

\begin{tabular}{ccc}
\hline Tahun & $\begin{array}{c}\text { Jumlah Sepeda Motor } \\
\text { (Unit) }\end{array}$ & $\begin{array}{c}\text { Kontribusi } \\
\text { (\%) }\end{array}$ \\
\hline 2010 & 5.153 & 17,06 \\
2011 & 6.202 & 20,54 \\
2012 & 6.434 & 21,30 \\
2013 & 6.201 & 2053 \\
2014 & 6.210 & 20,56 \\
\hline
\end{tabular}

Sumber Data: Samsat Manokwari, 2015

Peningkatan jumlah penduduk sejalan dengan permintaan kredit sepeda motor khususnya pada sepeda motor merek Honda. Tingginya permintaan kredit sepeda motor karena sepeda motor merupakan alat transportasi yang menjadi pilihan konsumen, dengan memiliki dan menggunakan sepeda motor dapat mempermudah dan mempercepat kebutuhan aktivitas masyarakat. Selain itu, sepeda motor lebih mudah dan lebih praktis di bandingkan dengan transportasi lainnya. Oleh karena itu kebutuhaan sepeda motor sebagai alat transportasi sangatlah tinggi, Selain praktis dan mudah dalam pengoperasian berkendara sepeda motor juga tepat untuk segala kondisi jalan dan menjadikan sepeda motor sebagai sarana transportasi bagi konsumen.

Faktor lain yang menyebabkan adanya permintaan kredit sepeda motor adalah banyaknya jumlah anggota dalam satu rumah tangga. Semakin banyak jumlah angggota maka kebutuhan untuk sarana transportasi semakin tinggi. Sepeda motor sangat penting untuk mendukung aktifitas kerja yang di lakukan sehari-hari. Tanpa kendaraan suatu aktivitas tidak dapat berjalan dengan baik. Hal ini di sebabkan karena terdapatnya perbedaan antara jarak atau lokasi tempat tujuan yang satu dengan tujuan yang lain, sehingga untuk mencapai tujuan tersebut di butuhkan kendaraan. Sepeda motor yang saat ini banyak digunakan oleh kalangan masyarakat adalah sepeda motor merek Honda dan Yamaha, tetapi yang akan di ambil dalam penelitian ini adalah sepeda motor merek 
Honda Berdasarkan permasalahan tersebut maka tujuan dari penelitian ini adalah untuk menganalisis faktor-faktor yang mempengaruhi permintaan kredit sepeda motor Honda di Kabupaten Manokwari.

Penelitian sebelumnya telah dilakukan terkait pembayaran kredit kendaraan bermotor. Tahapary (2007) menyimpulkan bahwa anggota keluarga berpengaruh negatif, sedangkan tingkat pendapatan dan pengetahuan berpengaruh positif terhadap kelancaran pembayaran kredit. Namun, tingkat kelancaran pembayaran kredit tidak sesuai dengan jangka waktu yang telah disepakati. Penelitian serupa oleh Qarina (2012) dan Alimuddin (2013) menyatakan pendapatan berpengaruh positif tetapi tidak signifikan, dan harga berpengaruh negatif dan signifikan terhadap permintaan kendaraan bermotor. Berdasarkan hasil penelitian terdahulu, penelitian ini menduga hubungan pengaruh antara pendapatan, jangka waktu kredit, harga dan ada tidaknya barang substitusi sebagai faktor yang mempengaruhi permintaan kredit kendaraan bermotor di Kabupaten Manokwari. Berikut Gambar 1 adalah gambar kerangka hubungan variabel.

Berdasarkan gambar dapat dilihat bahwa terdapat dua macam variabel yaitu variabel bebas dan variabel terikat. Variabel bebas yang digunakan yaitu pendapatan, jangka waktu pengembalian kredit, harga, dan barang subtitusi. Sedangkan variabel terikat yang digunakan yaitu permintaan kredit sepeda motor di Kabupaten Manokwari. Variabel pendapatan, jangka waktu pengembalian kredit, harga produk, barang subtitusi berpengaruh terhadap permintaan kredit sepeda motor. Apabila permintaan kredit sepeda motor meningkat maka akan menunjukkan pertumbuhan kredit sepeda motor, artinya semakin tinggi permintaan kredit sepeda motor maka berarti terdapat pertumbuhan kredit sepeda motor di Kabupaten Manokwari.

\section{Hipotesis}

Hipotesis merupakan jawaban sementara atau kesimpulan sementara terhadap permasalahan yang menjadi objek penelitian, yang kebenarannya masih perlu dibuktikan atau di uji secara empiris.

$\mathrm{H}_{0}$ : Tidak terdapat pengaruh pendapatan, jangka waktu kredit, harga produk dan barang subtitusi terhadap permintaan kredit sepeda motor Honda di Kabupaten Manokwari.

$\mathrm{H}_{1}$ : Terdapat pengaruh pendapatan, jangka waktu kredit, harga produk dan barang subtitusi terhadap permintaan kredit sepeda motor Honda di Kabupaten Manokwari.
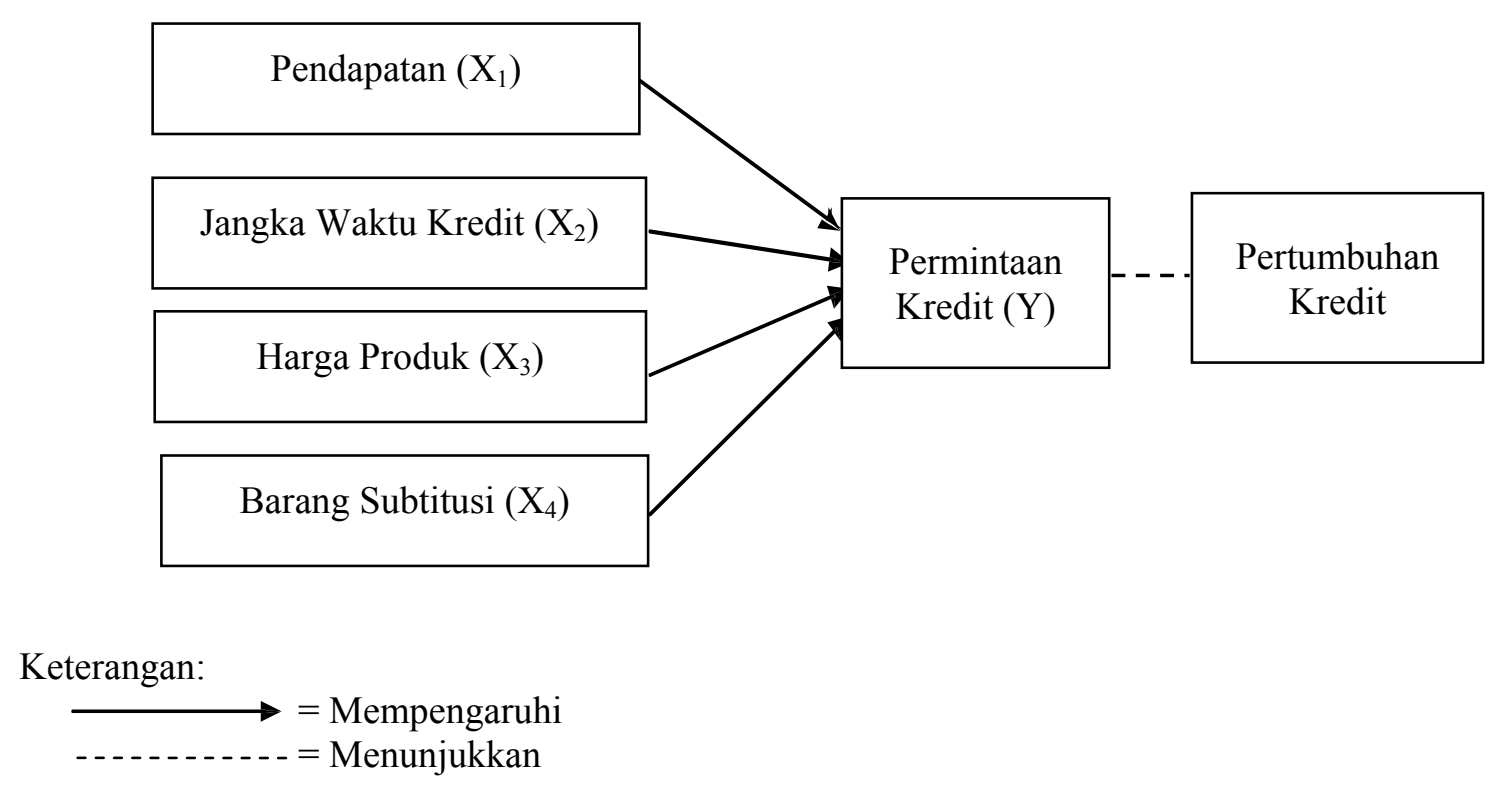

Gambar 1. Kerangka Hubungan Variabel 


\section{METODE PENELITIAN}

\section{Populasi dan Sampel}

Populasi berupa objek atau subjek yang mempunyai kualitas dan karakteristik tertentu dan membantu dalam penarikan kesimpulan penelitian (Sugiyono, 2008). Populasi dalam penelitian ini adalah debitur yang mengambil kredit sepeda motor Honda dengan rata-rata pertahun yaitu sebanyak 1.322 pada PT.Federal International Financial (FIF) di Kabupaten Manokwari.

Menurut Sugiyono (2008), sampel adalah bagian dari jumlah dan karakteristik yang dimiliki oleh populasi tersebut. Sampel dalam penelitian ini diambil dengan menggunakan teknik pengambilan sampel yaitu dengan Teknik accidental sampling. Menurut Sugiyono (2009), teknik accidental sampling yaitu peneliti memilih siap saja anggota populasi yang secara kebetulan bertemu dengan peneliti di anggap dapat memberikan informasi yang di perlukan. Untuk menentukan ukuran sampel penelitian dari populasi tersebut dapat digunakan rumus Slovin yaitu:

$$
n=\frac{N}{1+N e^{2}}
$$

Dimana:

$$
\begin{aligned}
\mathrm{n}= & \text { ukuran sampel } \\
\mathrm{N}= & \text { ukuran populasi yaitu pengguna motor } \\
& \text { Honda } \\
\mathrm{e}= & \text { persen kelonggaran ketidaktelitian karena } \\
& \text { kesalahan pengambilan sampel inginkan } \\
& \text { sebanyak } 10 \% .
\end{aligned}
$$

Berdasarkan rumus tersebut maka jumlah sampel yang di ambil dalam penelitian ini adalah 93 responden.

$$
\begin{aligned}
\mathrm{n} & =\frac{1.322}{1+1.322(10 \%)^{2}}=\frac{1.322}{1+13,22}=\frac{1.322}{14,22} \\
& =92,96 \approx 93
\end{aligned}
$$

\section{Teknik Pengumpulan Data}

Teknik pengumpulan data dalam penelitian ini menggunakan wawancara, kuesioner dan studi literatur. Menurut Sugiyono (2009), wawancara merupakan teknik pengumpulan data dengan mengajukan pertanyaan secara lisan untuk mengetahui hal-hal dari responden yang lebih mendalam. Pengumpulan data yang dilakukan dengan membaca buku-buku literatur, jurnaljurnal, internet, majalah dan penelitian terdahulu yang berkaitan dengan penelitian yang sedang dilakukan.

\section{Metode Analisa Data}

Metode analisa yang digunakan dalam penelitian ini adalah regresi linier berganda, yaitu untuk mengetahui seberapa besar pengaruh pendapatan, jangka waktu kredit, harga produk dan barang subtitusi terhadap permintaan kredit sepeda motor Honda di Kabupaten Manokwari. Adapun rumus persamaan regresi dalam pengujian hipotesis penelitian ini adalah:

$$
Y=\beta_{0}+\beta_{1} X_{1}+\beta_{2} X_{2}+\beta_{3} X_{3}+\beta_{4} X_{4}+e
$$

$$
\begin{aligned}
& \text { dimana: } \\
& \mathrm{Y} \quad=\text { Permintaan kredit } \\
& \beta_{0} \quad=\text { konstanta } \\
& \beta_{1}-\beta_{4}=\text { Koefisien regresi } \\
& \mathrm{X}_{1} \quad=\text { Pendapatan } \\
& \mathrm{X}_{2} \quad=\text { jangka waktu pengembalian kredit } \\
& \mathrm{X}_{3} \quad \text { = harga produk } \\
& \mathrm{X}_{4} \quad=\text { barang subtitusi } \\
& \mathrm{e}
\end{aligned}
$$

\section{Pengujian Hipotesis}

1. Uji t

Pengujian hipotesis secara parsial, dapat diuji dengan menggunakan rumus uji t. Uji t pada dasarnya menunjukkan seberapa jauh pengaruh satu variabel penjelas/independen secara individual dalam menerangkan variasi variabel independen (Ghozali, 2011). Pengujian hipotesis untuk membuktikan apakah $\mathrm{H}_{0}$ diterima atau ditolak yaitu menggunakan nilai probabilitas. Jika probabilitas $>0,05$ maka $\mathrm{H}_{0}$ ditolak dan jika probabilitas $<0,05$ maka $\mathrm{H}_{\mathrm{a}}$ diterima.

\section{Uji F}

Uji $\mathrm{F}$ atau yang disebut juga dengan uji simultan digunakan untuk menguji pengaruh variabel independen secara bersama-sama terhadap variabel dependen dari suatu persamaan regresi dengan menggunakan hipotesis statistik (Santoso, 2004). Jika probabilitas $>0,05$ maka 
$\mathrm{H}_{0}$ diterima dan jika probabilitas $<0,05$ maka $\mathrm{H}_{0}$ ditolak.

\section{Koefisien Determinasi $\left(\mathrm{R}^{2}\right)$}

Menurut Ghozali (2011:97), koefisien determinasi $\left(R^{2}\right)$ mengukur kemampuan model regresi yang ditentukan dalam menjelaskan variasi variabel independen. Nilai $R^{2}$ bernilai antara $0<R^{2}<100$. Nilai yang semakin mendekati satu menunjukkan bahwa variabelvariabel independen memberikan hampir semua informasi yang dibutuhkan untuk memprediksi variasi variabel dependen.

\section{Uji Asumsi Klasik}

Uji asumsi klasik dilakukan pada model regresi yang terdiri dari Uji Normalitas, Uji Multikolinearitas, dan Uji Heterokedastisitas.

\section{Definisi Operasional}

Untuk memperjelas dan memudahkan pemahaman terhadap variabel- variabel yang akan dianalisis dalam penelitian ini, maka perlu dirumuskan definisi operasional sebagai berikut:

1. Pendapatan $\left(X_{1}\right)$ adalah nilai rata-rata tiap bulan pendapatan konsumen yang mengajukan kredit sepeda motor dinyatakan dalam rupiah perbulan. Semakin tinggi nilai skor berarti nilai rata-rata pendapatan akan semakin tinggi.

2. Jangka waktu pengembalian kredit $\left(\mathrm{X}_{2}\right)$ adalah lamanya waktu pengambilan kredit yang diberikan pihak kreditur kepada debitur dinyatakan dalam satuan bulan. Semakin tinggi nilai skor berarti jangka waktu pengembalian kredit akan semakin lama.

3. Harga produk $\left(\mathrm{X}_{3}\right)$ adalah sejumlah uang yang harus dibayarkan apabila konsumen membeli sepeda motor secara tunai dinyatakan dalam rupiah. Semakin tinggi nilai skor yang ditentukan berarti harga produk akan semakin mahal.

4. Barang subtitusi $\left(\mathrm{X}_{4}\right)$ adalah barang yang sama dengan kendaraan bermotor tetapi yang membedakan adalah motor second dan motor baru. Untuk pemberian skor pada sepeda motor baru adalah 0 sedangkan untuk sepeda motor second adalah 1 . Artinya jika nilai scor sepeda second adalah 1 berarti permintaan sepeda motor akan semakin banyak.

5. Permintaan kredit sepeda motor $(\mathrm{Y})$ ditunjukan dengan berapa banyak permintaan kredit sepeda motor yang dimiliki dalam satuan unit. Semakin banyak jumlah sepeda motor yang dimiliki berarti semakin bertambah jumlah permintaan kredit sepeda motor.

Tabel 2. Uji Normalitas Dengan Menggunakan Metode Kolmogorov-Smirnow

One-Sample Kolmogorov-Smirnov Test

\begin{tabular}{llc}
\hline & & $\begin{array}{c}\text { Standardized } \\
\text { Residual }\end{array}$ \\
\hline $\mathrm{N}$ & & 93 \\
\hline Normal Parameters $^{\mathrm{a}}$ & Mean & 0.000 \\
\cline { 2 - 3 } & Std. Deviation & 0.972 \\
\hline Most Extreme & Absolute & 0.084 \\
\cline { 2 - 3 } Differences $^{\text {Positive }}$ & 0.084 \\
\cline { 2 - 3 } & Negative & -0.081 \\
\hline Kolmogorov-Smirnov Z & 0.809 \\
\hline Asymp. Sig. (2-tailed) & 0.529 \\
\hline
\end{tabular}

a. Test distribution is Normal.

Sumber: Data Primer Diolah, 2015

\section{HASIL DAN PEMBAHASAN}

Penelitian ini dilakukan dengan memberikan kuesioner kepada 93 responden yang memiliki kredit di PT. FIF Kabupaten Manokwari. Agar mendapatkan profil responden, maka dilakukan analisa deskripsi responden berdasarkan, pekerjaan usia, jenis kelamin, dan pendidikan tinggi. Secara umum, profil responden sebagai konsumen sepeda motor kredit di PT. FIF antara lain memiliki lebih banyak konsumen pria $(63,44 \%)$, bekerja sebagai pegawai swasta (32,26\%), berusia antara 19-30 tahun $(60,21 \%)$, dan merupakan lulusan SMA (48\%).

\section{Hasil Analisis Faktor Penentu Permintaan Kredit Pada PT. FIF}

Sebelum dilakukan pengujian pengaruh antar variabel terlebih dahulu dilakukan pengujian 
terhadap keberartian data secara keseluruhan yang terdiri dari uji asumsi klasik, analisis regresi berganda, dan uji statistik.

Uji normalitas dapat dilakukan melalui 3 cara yaitu dengan analisis grafik, uji statistik sederhana kortosis dan skewness, serta uji statistik non-parametrik Kolmogorov-Smirnov. Dalam penelitian ini pengujian dilakukan dengan menggunakan metode Kolmogorov-Smirnov, histogram dan analisis grafik. Dari tabel 2 diketahui bahwa data berdistribusi normal karena nilai Asymp. Sig. (2-tailed) sebesar 0.529 dan berada diatas nilai signifikan $(0,05)$. Asymp.Sig. (2-tailed) $>0,05$. Pengujian multikolinearitas dilakukan dengan menggunakan nilai VIF dan tolerance kurang dari 0,10 dan VIF tidak lebih dari 10.

Berdasarkan hasil pengujian multikolinearitas pada tabel 3 diketahui bahwa semua variabel independen memiliki nilai VIF lebih kecil dari 10, dan nilai tolerence lebih besar dari 0,1 sehingga dapat disimpulkan bahwa data bebas dari masalah multikolinearitas atau tidak ada multikolinearitas antara variabel bebas dalam model regresi sehingga model regresi layak digunakan.
Tabel 3. Uji Multikolinieritas

\section{Coefficients $^{\mathrm{a}}$}

\begin{tabular}{lcc}
\hline \multirow{2}{*}{\multicolumn{1}{c}{ Model }} & \multicolumn{2}{c}{ Collinearity Statistics } \\
\cline { 2 - 3 } & Tolerance & VIF \\
\hline Pendapatan & 0.894 & 1.116 \\
Jangka Waktu & 0.882 & 1.116 \\
Harga Produk & 0.985 & 1.015 \\
Barang Subtitusi & 0.950 & 1.011 \\
DFFIT & 0.962 & 1.023 \\
\hline
\end{tabular}

a. Dependent Variable: Permintaan Kredit Sumber: Data Primer Diolah, 2015

Tujuan uji heteroskedastisitas adalah menguji adakah ketidaksamaan variance dari residual satu pengamatan kepengamatan yang lain, jika hasilnya tetap maka disebut homoskedatisitas dan jika berbeda disebut heteroskedastisitas. Model regresi yang baik adalah homoskedastisitas atau yang tidak terjadi heteroskedastisitas. Uji heteroskedastisitas dapat dilakukan dengan scatterplot dengan memplotkan nilai ZPRED (nilai prediksi) dengan SRESED (nilai residualnya).

\section{Seatterplot}

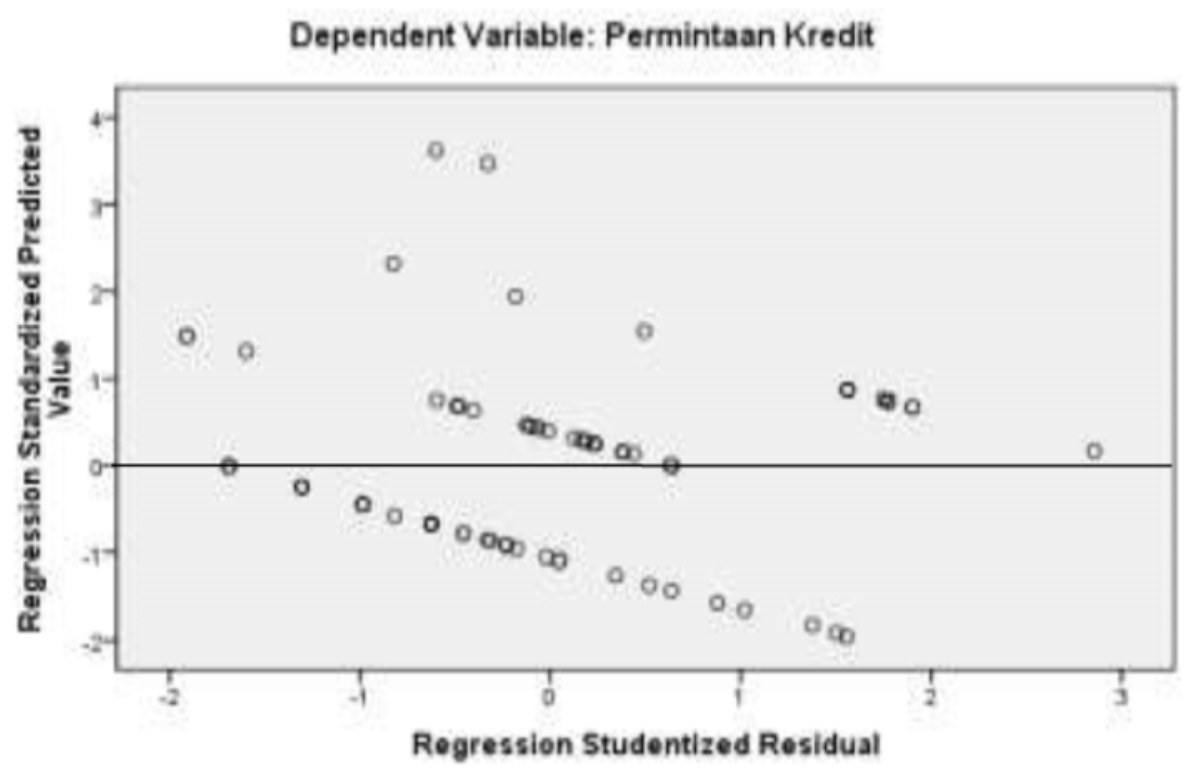

Gambar 2. Uji Heteroskedastisitas dengan Menggunakan Metode Analisis Grafik 
Berdasarkan tampilan pada scatterplot terlihat bahwa plot menyebar secara acak diatas maupun di bawah angka nol pada sumbu regresion studenttized resedual. Oleh karena itu maka berdasarkan uji heteroskedastisitas menggunakan metode analisis grafik, pada model regresi yang terbentuk dinyatakan tidak terjadi gejala hetroskedastisitas, dan model ini layak digunakan.

Selanjutnya, untuk menguji ada tidaknya korelasi antara kesalahan penggangu pada periode $t$ dengan kesalahan pengganggu pada periode $\mathrm{t}-1$ (sebelumnya) dilakukan uji autokorelasi dengan menggunakan pengujian Durbin Watson.

Pada output model summary terdapat nilai durbin-watson sebesar 1,760. Pengambilan keputusan pada asumsi ini memerlukan dua nilai dari tabel Durbin Watson yaitu nilai dL dan dU dengan $\mathrm{k}=$ jumlah variabel bebas dan $\mathrm{n}=$ ukuran sampel. Tabel DW menunjukkan nilai dU sebesar 1.751 dan nilai dL sebesar 1.579 dengan jumlah sampel 95. Sedangkan jumlah sampel 90 dengan nilai dL sebesar 1.566 dan nilai dU sebesar 1.751. Untuk membandingkan dengan nilai $\mathrm{DW}$ dan nilai $\mathrm{dU}$, dL maka di gunakan sampel (n) yaitu 95.

Posisi DW berada pada daerah menerima Ho. Karena nilai DW lebih besar $(1,760)$ dari dL
$(1,579)$ dan lebih kecil dari 4-1,579=2,421 selanjtunya nilai DW lebih kecil $(1,760)$ dari $\mathrm{dU}$ $(1,755)$ dan lebih kecil dari $4-1,755=2,245$, jadi dapat disimpulkan bahwa jika dilihat dari Durbin Watson $(1,760)$ terletak antara dU dengan 4-dU, maka persamaan regresi tersebut tidak mengandung masalah auto korelasi atau tidak ada autokorelasi positif maupun negatif sehingga model bebas dari problem autokorelasi.

Pengujian linearitas dilakukan untuk mengetahui model yang dibuktikan merupakan model linear atau tidak. Untuk mendeteksi apakah model sebaiknya menggunakan persamaan liniear atau tidak, maka digunakan metode Ramsey.

Berdasarkan output pada persamaan regersi pertama diperoleh $\mathrm{R}^{2}$ lama sebesar 0,075, sedangkan pada persamaan regresi yang kedua diperoleh nilai $\mathrm{R}^{2}$ baru 0,729 . Dengan besarnya nilai $\mathrm{F}$ hitung dapat diperoleh, yaitu sebagai berikut:

$$
\begin{gathered}
F=\frac{\frac{R^{2} \text { new }-R^{2}}{m}}{\frac{1-R^{2} \text { new }}{n-k}}=\frac{(0,729-0,052) / 1}{(1-0,729) /(93-5)} \\
=219,838
\end{gathered}
$$

Karena nilai $\mathrm{F}_{\text {hitung }}=219,838>\mathrm{F}_{\text {tabel }}=3,947$ maka dapat disimpulkan bahwa model regresi yang benar adalah linier.

Tabel 4. Uji Autokorelasi Durbin Watson

Model Summary

\begin{tabular}{cccrcc}
\hline Model & $\mathbf{R}$ & $\begin{array}{c}\mathbf{R} \\
\text { Square }\end{array}$ & $\begin{array}{c}\text { Adjusted R } \\
\text { Square }\end{array}$ & $\begin{array}{c}\text { Std. Error of the } \\
\text { Estimate }\end{array}$ & Durbin-Watson \\
\hline 1 & $0,854^{\mathrm{a}}$ & 0,729 & 0,712 & 0,433 & 1,760 \\
\hline
\end{tabular}

a. Predictors: (Constant), DFFIT, Barang Subtitusi, Harga Produk, Pendapatan, Jangka Waktu Variable: b. Dependent Permintaan Kredit Sumber: Data Primer Diolah 2015

Tabel 5. Uji Linearitas Menggunakan Metode Ramsey

\begin{tabular}{ccccc}
\multicolumn{5}{c}{ Model Summary $^{\mathbf{c}}$} \\
\hline Model & R & R Square & Adjusted R Square & Std. Error of the Estimate \\
\hline 1 & $0.227^{\mathrm{a}}$ & 0.052 & 0.008 & 0.806 \\
2 & $0.854^{\mathrm{b}}$ & 0.729 & 0.714 & 0.434
\end{tabular}

a. Predictors: (Constant), Barang Subtitusi, Harga Produk, Pendapatan, Jangka Waktu

b. Predictors: (Constant), Dffit, Barang Subtitusi, Harga Produk, Pendapatan, Jangka Waktu

c. Dependent Variable: Permintaan Kredit

Sumber: Data Primer Diolah, 2015

Journal of Fiscal and Regional Economy Studies 


\section{Hasil Analisis Regresi Linear Berganda}

Analisis regresi linear berganda yang telah dilakukan diperoleh koefisien regresi, nilai $t_{\text {hitung dan tingkat signifikansi sebagaimana }}$ ditampilkan pada tabel 6 .

Dari hasil tersebut apabila ditulis persamaan regresi dalam bentuk unstandardized coefficients sebagai berikut:

$$
\begin{aligned}
\mathrm{Y}= & 1,964-0,250 \mathrm{X}_{1}+0,096 \mathrm{X}_{2}+ \\
& 0,169 \mathrm{X}_{3}-0,394 \mathrm{X}_{4}+0,303
\end{aligned}
$$

Keterangan:

$\mathrm{Y}=$ permintaan kredit

$\mathrm{X}_{1}=$ pendapatan

$\mathrm{X}_{2}=$ jangka waktu pengemabalian kredit

$\mathrm{X}_{3}=$ harga produk

$\mathrm{X}_{4}=$ barang subtitusi

$\mathrm{e}=$ standar eror

Hasil estimasi diatas dapat dijelaskan bahwa pengaruh variable bebas yaitu pendapatan, jangka waktu pengembalian kredit, harga produk dan barang subtitusi terhadap variabel dependen yaitu permintaan kredit sepeda motor Honda pada PT. FIF sebagai berikut:

\section{Konstanta (Intersep)}

Sesuai persamaan dapat dilihat bahwa nilai konstanta sebesar 1,964 yang berarti bahwa nilai permintaan kredit sebesar 1,964 dengan jumlah motor 2 unit. Apabila pendapatan, jangka waktu, harga produk dan barang subtitusi bernilai 0 (nol) atau konstan.

2. Pendapatan $\left(\mathrm{X}_{1}\right)$

Sesuai persamaan dapat diperoleh nilai koefiseien regresi pendapatan bernilai negatif sebesar -0,250. Jika nilai skor pendapatan meningkat maka permintaan kredit menurun sebesar 25\%. Dari hasi regresi Pendapatan berpengaruh negatif tetapi signifikan terhadap permintaan kredit.

Pendapatan berpengaruh negatif, karena ketika pendapatan meningkat, maka permintaan kredit sepeda motor tidak ikut meningkat. Ini diakibatkan karena sebagian masyarakat lebih memilih membeli motor secara tunai daripada harus membeli sepeda motor secara kredit. Selain itu, sebagian dari masyarakat juga lebih memilih menghabiskan pendapatannya untuk hal yang lebih penting, seperti biaya pendidikan, biaya kesehatan atau biaya primer lainnya. Penelitian ini tidak sesuai dengan penelitian sebelumnya menurut Anindika (2009), Juwani (2013), Tahapary (2007) yang mengatakan pendapatan berpengaruh positif dan signifikan. Sedangkan menurut Alimuddin (2013), pendapatan berpengaruh positif juga tetapi tidak signifikan terhadap permintaan kendaraan roda dua.

Tabel 6. Hasil Analisa Regresi Linear Berganda

\begin{tabular}{lccccc}
\hline \multirow{1}{*}{ Model } & \multicolumn{2}{c}{$\begin{array}{c}\text { Unstandardized } \\
\text { Coefficients }\end{array}$} & $\begin{array}{c}\text { Standardized } \\
\text { Coefficients }\end{array}$ & & \\
\cline { 2 - 4 } & \multicolumn{1}{c}{ B } & Std. Error & Beta & t & Sig. \\
\hline (Constant) & 1.964 & 0.303 & & 6.482 & 0.000 \\
Pendapatan & -0.250 & 0.074 & -0.200 & -3.389 & 0.001 \\
Jangka Waktu & 0.096 & 0.096 & 0.059 & 1.000 & 0.320 \\
Harga Produk & 0.169 & 0.065 & 0.146 & 2.597 & 0.011 \\
Barang Subtitusi & -0.394 & 0.156 & -0.145 & -2.524 & 0.013 \\
DFFIT & 14.592 & 0.989 & 0.839 & 14.750 & 0.000 \\
\hline
\end{tabular}

Dependent Variable: Permintaan Kredit

Sumber: data primer diolah 2015 


\section{Jangka Waktu Pengembalian Kredit $\left(\mathrm{X}_{2}\right)$}

Sesuai persamaan dapat diperoleh nilai koefisien regresi Jangka Waktu Pengembalian kredit sebesar, 0,096. Jika nilai skor jangka waktu pengembalian kredit meningkat maka permintaan kredit akan bertambah sebesar 96\%. Jangka waktu pengembalian kredit berpengaruh positif tetapi tidak signifikan terhadapd permintaan kredit. Peneitian ini sesuai dengan penelitian yang dilakukan Alimuddin (2013), yang mengatakan jangka waktu pengembalian kredit mempunyai pengaruh positif tetapi tidak signifikan terhadap permintaan kendaraan. Sedangkan menurut Anindika (2009), jangka waktu pengembalian kredit tidak signifikan tetapi berpengaruh positif.

\section{Harga Produk $\left(\mathrm{X}_{3}\right)$}

Sesuai persamaan dapat diperoleh nilai koefisien regresi harga produk sebesar 0,169. Jika nilai skor harga produk meningkat maka akan meningktakan permintaan kredit sebesar $16,9 \%$. Dari hasil regresi harga produk berpengaruh positif dan signifikan terhadap permintaan kredit. Penelitian ini tidak sejalan dengan penelitian yang dilakukan oleh Alimuddin (2013), yang mengatakan harga produk berpengaruh negatif tetapi signifikan terhadap permintaan kendaraan bermotor roda dua di Kota Makasar.

\section{Barang Subtitusi}

Sesuai persamaan dapat diperoleh nilai koefisien regresi barang subtitusi sebesar $-0,394$. Jika nilai skor terhadap barang subtitusi adalah sepeda motor second meningkat maka akan menurunkan permintaan kredit sebesar 39,4\%. Dari hasil regresi barang subtitusi sepeda motor second berpengaruh negatif tetapi signifikan terhadap permintaan kredit sepeda motor. Artinya jika sepeda motor second berpengaruh negatif maka akan menurunkan permintaan kredit sepeda motor karena masyarakat lebih memilih untuk melakukan permintaan kredit terhadap sepeda motor baru. Hal ini menunjukan bahwa kualitas tehadap sepeda motor second tidak menjamin masyarkat untuk melakukan permintaan kredit.

\section{Hasil Uji F}

Untuk mengetahui pengaruh variabel bebas yaitu pendapatan, jangka waktu pengembalian kredit, harga produk dan barang subtitusi secara bersama-sama berpengaruh terhadap variabel terikat yaitu permintaan kredit dilakukan uji $\mathrm{F}$. Analisis uji $\mathrm{F}$ dimaksudkan untuk membuktikan dari penelitian yang menyatakan bahwa variable bebas mempunyai pengaruh yang positif terhadap permintaan kredit sepeda motor Honda dengan membuktikan $\mathrm{F}$ hitung yang di hasilkan oleh regresi linear berganda dengan alpa 0,05 . Adapun tolak ukur penerimaan atau penolakan $\mathrm{H}_{\mathrm{O}}$, adalah sebagai berikut:

$\mathrm{H}_{1}$ ditolak jika probabilitas $>\alpha=0,05$

$\mathrm{H}_{1}$ di terima jika probabiitas $<\alpha=0,05$

Berdasarkan hasil uji anova pada tabel 7 didapatkan $F_{\text {hitung }}$ sebesar 46,825 dan memiliki nilai probabilitas sebesar 0,000 . Karena nilai probabilitas lebih kecil dari nilai alpha 0,05 $(0,000>0,05)$, ini menunjukan bahwa variabel pendapatan $\left(\mathrm{X}_{1}\right)$, jangka waktu pengembalian kredit $\left(\mathrm{X}_{2}\right)$, harga produk $\left(\mathrm{X}_{3}\right)$ dan barang subtitusi $\left(\mathrm{X}_{4}\right)$ secara simultan mempengaruhi variabel permintaan kredit $(\mathrm{Y})$. Jadi dapat disimpulkan bahwa $\mathrm{H}_{0}$ di tolak dan $\mathrm{H}_{1}$ di terima.

Tabel 7. Hasil Uji Simultan (F)

\begin{tabular}{llcrcrr}
\multicolumn{8}{c}{ ANOVA $^{\mathbf{b}}$} \\
\hline & Model & Sum of Squares & Df & Mean Square & F & Sig. \\
\hline 1 & Regression & 43.949 & 5 & 8.790 & 46.825 & $0.000^{\mathbf{a}}$ \\
& Residual & 16.331 & 87 & 0.188 & & \\
\cline { 2 - 6 } & Total & 60.280 & 92 & & & \\
\hline
\end{tabular}

a. Predictors: (Constant), DFFIT, Jangka Waktu, Harga Produk, Barang Subtitusi, Pendapatan

b. Dependent Variable: Permintaan Kredit

Sumber: Data Primer Diolah 2015 
Nilai koefisien determinasi adalah antara nol dan satu. Nilai koefisien dapat dilihat pada table 5. Dari hasil perhitungan regresi dapat diketahui bahwa koefisien determinasi Hasil analisis menunjukan bahwa nilai $\mathrm{R}$ Square adalah sebesar 0,729 hal ini berarti dapat disimpulkan bahwa kemampuan seluruh variabel independent yaitu pendapatan, jangka waktu pengembalian kredit, harga produk dan barang subtitusi, untuk menjelaskan variasi pada variabel dependen yaitu permintaan kredit sepeda motor adalah sebesar $0,729 \%$ sedangkan sisanya sebesar $100-72,9=27,1 \%$ dijelaskan oleh faktor lain yang tidak dijelaskan dalam model regresi yang diperoleh.

\section{Hasil Uji t}

Untuk melihat apakah variabel independen memang benar dapat mempengaruhi variabel dependennya secara persial, digunakan uji t. Hipotesis yang digunakan adalah sebagai berikut:

$\mathrm{H}_{0}: \mathrm{b}_{1}, \mathrm{~b}_{2}, \mathrm{~b}_{3}$ dan $\mathrm{b}_{4} \leq 0$, artinya variabel independen tidak mempengaruhi variabel dependen.

$\mathrm{H}_{\mathrm{a}}: \mathrm{b}_{1}, \mathrm{~b}_{2}, \mathrm{~b}_{3}$ dan $\mathrm{b}_{4}>0$, artinya variabel independen mempengaruhi variabel dependen.

Pengujian hopotesis untuk membuktikan apakah $\mathrm{H}_{0}$ diterima atau ditolak menggunakan nilai probabilitas. Jika probabilitas $>0,05$, maka $\mathrm{H}_{0}$ diterima, jika probabilitas $\leq 0,05$ maka $\mathrm{H}_{0}$ ditolak.

Hasil analisis uji $\mathrm{t}$ adalah sebagai berikut:

\section{Koefisien regeresi Variabel pendapatan}

Variabel ini memiliki nilai probabilitas 0,001 $<0,05$ yang berati bahwa variabel pendapatan secara parsial berpengaruh terhadap permintaan kredit sepeda motor dengan tingkat kepercayaan 95\%. Karena nilai probabilitas lebih kecil dari alpha dengan demikian Ho ditolak dan $\mathrm{H} 1$ diterima. Penelitian ini sejalan dengan penelitian sebelumnya menurut Allimudin (2013), Juwiani (2013), yang mengatakan pendapatan berpengaruh secara parsial terhadap permintaan kredit. Dan sesuai dengan teori yang mengatakan semakin tinggi pendapatan maka kesediaan untuk membeli barang semakin tinggi.

2. Koefisien regresi variabel jangka waktu pengembalian kredit

Variabel ini memiliki nilai probabilitas $0,320>$ 0,05 yang berarti bahwa variabel jangka waktu pengembalian tidak berpengaruh secara parsial terhadap permintaan kredit dengan tingkat kepercayaan 95\%. Karena nilai probabilitas lebih besar dari alpha dengan demikian Ho diterima dan $\mathrm{H}_{1}$ ditolak. Penelitian ini tidak sesuai dengan penelitan sebelumnya karena penelitian sebelumnya tidak menjelaskan pengaruh secara parsial terhadap variabel terikat dan tidak sesuai dengan teori yang mengatakan semakin lama jangka waktu pengembalian kredit sepeda motor maka permintaan akan kredit sepeda motor semakin meningkat.

\section{Koefisien regresi variabel harga produk}

Variabel ini memiliki nilai probabilitas $0,011<$ 0,05 yang berarti bahwa variabel harga produk secara parsial berpengaruh terhadap permintaan kredit dengan tingkat kepercayaan 95\%. Karena nilai probabilitas lebih kecil dari alpha dengan demikian Ho ditolak dan $\mathrm{H} 3$ diterima. Penelitian ini tidak sesuai dengan penelitan sebelumnya karena penelitian sebelumnya tidak menjelaskan pengaruh secara parsial terhadap variabel terikat. Tetapi sesui dengan teori yang mengatakan sesuai dengan teori yang mengatakan bahwa Semakin tinggi harga sepeda motor maka permintaan untuk kredit akan semakin tinggi pula.

\section{Koefisien regresi barang subtitusi produk}

Variabel ini memiliki nilai probabilitas $0,013<$ 0,05 yang berarti bahwa variabel barang subtitusi secara parsial berpengaruh terhadap permintaan kredit dengan tingkat kepercayaan 95\%. Karena nilai probabilitas lebih besar dari alpha dengan demikian $\mathrm{HO}$ ditolak dan $\mathrm{H} 4$ diterima. Teori barang subtitusi mengatakan apabila kualitas barang lain lebih rendah, maka orang akan lebih memilih untuk membeli barang lain tersebut dan sebaliknya. Dalam penelitan sebelumnya tidak ada yang menggunakan variabel barang subtitusi jadi tida bisa debuktikan 
apakah ada pengaruh secara parsial terhadap variabel terikat dengan penelitian sebelumnya.

\section{KESIMPULAN}

Kesimpulan penelitian terdiri dari beberapa poin sebagai berikut:

1. Faktor-faktor yang mempengaruhi permintaan kredit sepeda motor Honda di Kabupaten Manokwari yang terdiri dari pendapatan, jangka waktu pengembalian kredit, harga produk dan barang subtitusi.

2. Hasil pengujian secara parsial menunjukan bahwa variable pendapatan, harga produk dan barang subtitusi secara persial berpengaruh dan signifikan terhadap permintaan kredit sepeda motor Honda di Kabupaten Manokwari. Sedangakan variabel jangka waktu secara parsial tidak berpengaruh terhadap permintaan kredit sepeda motor Honda di Kabupaten Manokwari pada.

3. Untuk hasil uji simultan dari keempat variabel yaitu pendapatan, jangka waktu pengembalian kredit, harga produk, dan barang subtitusi secara sumultan atau secara bersama-sama berpengaruh terhadap permintaan kredit sepeda motor Honda.

4. Hasil analisis regresi linear berganda menyatakan bahwa variabel pendapatan dan barang subtitusi berpengaruh negatif terhadap permintaan kredit sepeda motor Honda. Pendapatan berpengaruh negatif karena semakin tinggi pendapatan maka konsumen akan memilih untuk melakukan permintaan secara tunai. Sedangkan barang subtitusi yaitu sepeda motor second berpengaruh negatif karena motor second merupakan barang pengganti, hal ini sesuai dengan teori yang mengatakan Jika harga barang pengganti bertambah murah maka, barang yang digantikannya akan mengalami pengurangan dalam permintaannya.

\section{DAFTAR PUSTAKA}

Alimuddin. 2013. Analisis Faktor-Faktor Yang Mempengarui Permintaan Kredit Kendaraan Roda Dua Di Kota Makassar. Skripsi diterbitkan. Makasar. Fakultas Ekonomi dan Bisnis Universitas Hasanuddin Makassar.

Anindika, R., 2009. Analisis Faktorfaktor Yang Mempengaruhi Besarnya Pengambilan Kredit Oleh Masyarakat Pada Perum Pegadaian (Studi Kasus Di Perum Pegadaian Cabang Klaten) (Doctoral Dissertation, Universitas Sebelas Maret). Semarang.

Ghozali, Imam. 2011. Analisis multivariative SPSS. Semarang: Badan Penerbit Universitas Diponegoro.

Juwani., Pratiwi Utami, 2013. Analisis Faktor Yang Mempengaruhi Permintaan Kredit Pemilikan Rumah Pada Bank Umum Di Kota Makassar (Doctoral Dissertation). Universitas Hasanuddin, Makassar.

Qarina, 2012. Analisis Faktor Yang Mempengaruhi Permintaan Kredit Sepeda Motor Di Kota Makassar. Skripsi Fakultas Ekonomi Dan Bisnis, Universitas Hasanuddin Makassar.

Samuelson, Paul A. 1993. Mikroekonomi. Edisi keempatbelas. Jakarta: Erlangga. Suyatno, Thomas. 2003. Dasar dasar Perkreditan: Edisi Keempat. PT Gramedia Pustaka Utama. Jakarta.

Santoso, S., 2004. Latihan SPSS Statistik Parametrik. Bumi Aksara. Jakarta.

Sugiyono. 2009. Metode Penelitian Pendidikan Pendekatan Kuantitatif, Kualitatif, dan R\&D. Penerbit Alfabeta. Bandung.

Sugiyono. 2008. Metode Penelitian Kuantitatif, Kualitatif, dan R\&D. Penerbit Alfabeta. Bandung.

Tahapary, Nurjana, 2007, Analisis kelancaran pembayaran kredit kendaraan bermotor di Kabupaten Manokwari. Skripsi Sarjana Fakultas Ekonomi Dan Bisnis. Manokwari. 